\title{
Selected Reference Books of 1970-71
}

\section{INTRODUCTION}

$\mathrm{T}$ HIS ARTICLE CONTINUES the semiannual series originally edited by Constance M. Winchell. Although it appears under a byline, the list is actually a project of the Reference Department of the Columbia University Libraries, and notes are signed with the initials of the individual staff members. ${ }^{1}$

Since the purpose of the list is to present a selection of recent scholarly and foreign works of interest to reference workers in university libraries, it does not pretend to be either well balanced or comprehensive. Code numbers (such as AA71, 1DB4) have been used to refer to titles in the Guide to Reference Books and its supplements. ${ }^{2}$

\section{BIBLIOGRAPHY}

Catalogo dei libri italiani in commercio, [v.1- ]. Milan, Associazione Italiana Editori, 1970- . (v.1, 864p., \$27.50) 71-19147.

As part of its centenary celebration the Associazione Italiana Editori has issued a new Italian "books in print" listing 52,000 works published in Italy and currently available from 341 Italian publishing houses. Material is arranged by author and by title. Entries in both author and title sections are identical, derived from information supplied by the publishers. Entries are

1 Diane Goon, Rita Keckeissen, Georgia Lanzano, Eileen McIlvaine, Mary Ann Miller, Janet Schneider, Nancy Schroeder; School of Library Service, Evelyn Lauer.

2 Constance M. Winchell, Guide to Reference Books (8th ed.; Chicago: American Library Association, 1967); Supplement I (Chicago: ALA, 1968); Supplement II (Chicago: ALA, 1970). fairly full, giving author's name, title, edition, date, size, pagination, price and publisher; in some cases data on illustrations, maps, and number of printings are also indicated. A list of publishers' addresses is included.

Some details may prove disconcerting to the Anglo-American user. There are no cross-references from secondary authors or from the less common variations of names: the user must be prepared to search "Descartes, René" under "Cartesio, Renato" and "Marcus Aurelius" under "Aurelio, Marco." Corporate body proceedings are entered only in the title index under "Atti," "Memorie," etc. Plans call for the addition of a subject index "soon," and for bringing the complete catalog up to date on a biennial basis. This would produce a more current record of Italian books in print than the Associazione's previous effort, Catalogo collettivo della libreria italiana (Guide AA564). $-D . G$.

Le catalogue de l'édition française, 1970- . [Paris], VPC Livres; [Port Washington, N.Y.], Paris Publications, [1971- ]. Annual. (1970 in 4v., \$125)

Contents, 1970: v.1, Classement alphabétique par auteurs; v.2, Classement alphabétique par titres; v.3-4, Classement par sujets.

If it was "French Books in Print" that you ordered all those months ago, this is the publication you'll be receiving. Despite the long delay ("Blame the computer," the publishers seem to imply), this ambitious new work is no less welcome. It attempts to list French-language books in print throughout the world-some 15,000 of them from more than a thousand publishers in thirty-three countries in this first edition. Author, title, and subject (according to the main divisions of the Universal Decimal Classification) listings in separate volumes make for easy handling, but the subject sec- 
tion does not seem sufficiently unwieldy to require division into two volumes. Prefatory and explanatory matter appears in English as well as in French. A list of publishers' addresses is conveniently repeated at the end of each volume, as is an alphabetical list of "collections" or publishers' series.E.S.

National Union Catalog, 1956 through 1967; a Cumulative Author List Representing Library of Congress Printed Cards and Titles Reported by Other American Libraries. Totowa, N.J.: Rowman and Littlefield, [1970- ]. \$2100.

Contents: v.1-15, A-Broi.

Designed as a supplement to the National Union Catalog; Pre-1956 Imprints (Suppl. 2AA12), this is a cumulation of the fourth (1958-62) and fifth (1963-67) supplements of the National Union Catalog (Guide AA65), plus the register of additional locations appended to the fifth supplement. (1956-57 imprints, it will be remembered, were repeated in the 1958-62 cumulation, making this a continuous record.) To be in 120 volumes, the set will be welcomed by librarians not only because it will reduce searching time, but also because it is particularly well designed. Each entry is provided with an identifying number for easy reference. Information from the register of additional locations has been incorporated into the volume in which the entry occurs, and the existence of additional locations for a given entry is indicated by a star, eliminating unnecessary checking. As a further aid a list of library symbols is included at the back of every volume. Coverage of materials in non-Roman alphabets is the same as in the original sets. - N.S.

\section{INTERLIBRARY LOAN}

Thomson, Sarah Katharine. Interlibrary Loan Procedure Manual. Chicago: Interlibrary Loan Committee, American Library Association, 1970. 116p. $\$ 4.50$ pa. 71-125942.

Let's make this one a best-seller! For too many years, not only the bulk of the interlibrary lending, but the burden of verifying and "unscrambling" bad citations have rested with the large research libraries. This lit- tle guide could go far toward placing the borrowing privilege in its proper perspective and toward making the entire interlibrary loan process a more efficient one. The national code is reproduced and fully annotated; instructions for both borrowing and lending libraries are carefully spelled out; photocopy, copyright, and reprint problems are considered; and attention is given to such matters as requesting locations from the Union Catalog Division of Library of Congress, teletype requests, and dissertations on microfilm. The Manual should, at some point, be required reading for every library school student as well as for every librarian now involved in interlibrary loan work.-E.S.

\section{JOURNALISM}

Price, Warren C., and Pickett, Calder M. An Annotated Journalism Bibliography, 1958-1968. Minneapolis: University of Minnesota Press, [1970]. 285p. \$12. 70-120810.

Taking over from the late Warren Price, Mr. Pickett here presents an annotated bibliography of nearly 2,200 items. The volume forms a supplement to Price's very useful bibliography, The Literature of Journalism (Guide AG40), but differs from the parent work in arrangement: it employs a main-entry listing rather than a classed arrangement. A detailed index with liberal cross-referencing makes for efficient use. Some pre-1958 items not included in the original Price compilation have been added. With its many references to histories of individual magazines and newspapers, biographies of journalists, and works on varied aspects of journalism and news media this makes a valuable addition to the reference collection.-E.S.

\section{DisSERTATIONS}

Dickson, Diane, and Dossor, Carol. World Catalogue of Theses on the Pacific Islands. Honolulu: University of Hawaii Press, 1970. 123p. \$4.25 NZ. 70-119794.

Shulman, Frank J. Japan and Korea; an Annotated Bibliography of Doctoral Dissertations in Western Languages, 18771969. Chicago: American Library Association, 1970.340 p. $\$ 6.95$ pa. 71-127675. 
Add to the growing collection of dissertation bibliographies these two useful lists. Both are international and interdisciplinary in scope. The Dickson and Dossor bibliography includes master's theses as well as doctoral dissertations, and employs a geographical arrangement (with some topical breakdown) within four principal divisions: Oceania, Melanesia, Micronesia, and Polynesia. Cut-off date for entries was June 30,1968 ; there is an author index.

Shulman's list includes nearly 2,600 Western-language dissertations from the long period indicated. A classed arrangement is used, with author and institutional indexes. The work is effectively supplemented by a broader, quarterly listing of dissertations recently completed and in progress which Professor Shulman compiles for the Newsletter of the Association for Asian Studies. This list covers the whole of Asia, and first appeared in the Newsletter for May 1969.-E.S.

Dissertation Abstracts International. Retrospective Index, v.1-29. [Ann Arbor, Mich.], University Microfilms, 1970. 9v. in 11. \$995. 39-21214.

Contents: v.1, Mathematics and Physics; v.2, Chemistry; v.3, Earth/Life Sciences (in 2v.); v.4, Psychology/Sociology/Political Science; v.5, Social Sciences; v.6, Engineering; v.7, Education (in 2v.); v.8, Communication / Information / Business / Literature/Fine Arts; v.9, Author Index. (Specific volumes may be purchased separately.)

Cumulated indexes are always welcome reference tools, and this new example, incorporating the virtues and vices of computer keyword indexing, will be heavily used. The "principal words in each title" provide the terms under which dissertations are listed, chronologically, within the broad categories used in DAI and its predecessors. Given in each listing are title, author, university, reference to the abstract, and order number. This information is complete in multiple listings.

The "Comprehensive Subject Index" in each volume supplies cross-references for coverage of a subject, and the "How to Use the Index" section of the prefatory material should be read. Typical of the computer indexing problems that confront the user are these: In the author index the appellations "Jr." and "Sister," when they follow a comma after a surname, themselves file as given names, thus making it easy to miss the name sought. In other volumes a keyword preceded by quotation marks files in an alphabet printed before the alphabet of keywords without quotation marks. Running heads are for keywords only, and do not include category or subdivision, so that constant reference must be made to the table of contents. Less serious for the searcher, but marring the index as a whole, is the great quantity of useless listings. For example, persons as subjects are found listed under forename and middle name as well as under surname if all three are in a dissertation title. Eleven listings were found for one dissertation in history when four would have sufficed. This feature, minimized by the editors, partly accounts for the enormous length of the work and presumably for a share of production costs and selling price.-R.K.

\section{PhILOSOPHY}

Matczak, Sebastian A. Philosophy: $a$ Select, Classified Bibliography of Ethics, Economics, Law, Politics, Sociology. Louvain: Nauwelaerts, 1970. 308p. $\$ 16.50$. (Philosophical questions ser., 3) 72-80678.

This bibliography offers an interdisciplinary approach to research in ethics, relating ethics to fields whose subject matter involves ethical questions-economics, law, politics, and sociology. The chapter dealing with each of these fields is subdivided into general and special studies, and further subdivided by period, country, individual, and bibliographical format when these are applicable. Since the author has directed his work toward English-speaking students, books and articles in English predominate; those in other languages are listed separately, and available English translations are indicated. Although ethics is the field in which the compiler appears most at home, the chapters on economics and politics seem almost equally strong; that on sociology less so. 
As a basic bibliography for Englishspeaking students, Philosophy succeeds admirably, with one major exception. Its focus on the western world ignores developing "Third World" peoples; racism is equated with Aryanism, and the latest imprint noted for African sociological sources is 1936. Addition of a detailed subject index would have facilitated the location of such entries as "Atom Bomb" and "Birth Control" under "Ethics-Special Questions." Such improvements would make more valuable a bibliography which is informative and pleasurable to consult. The study of ethics should be a vigorous and rewarding pursuit, and Professor Matczak has done much to make it so.-D.G.

\section{RELIGION}

Harvey, Anthony Ernest. The New English Bible: Companion to the New Testament. [Cambridge, Eng.], Oxford University Press; Cambridge University Press, 1970. 850p. \$9.95. 73-141049.

Dr. Harvey has produced for the layman a very workable gloss to the New Testament of the New English Bible. It attempts to provide cultural, historical, literary, and theological background to the bare story line of the Gospels, the Letters of the Apostles, the Acts, and the Revelation of John. Arrangement is in order of precedence in the New Testament, and then line by line; thus the work is rather more a gloss than a "companion." Subject approach is through the index, which includes such topics as "personified evil" and "irrational element in conduct." The work is obviously better suited to the user who wants explication of a particular passage than to one who would like information about a topic such as the influence of Hellenistic thought on the Bible. Addition of a bibliography or bibliographic notes would have increased the value of this attractive and very readable guide.-G.L.

Jedin, Hubert; Latourette, Kenneth Scott; and Martin, Jochen, eds. Atlas zur Kirchengeschichte; die christlichen Kirchen in Geschichte und Gegenwart. Rev. by Jochen Martin. Freiburg: Herder, [1970]. 83,152 , xxxviip. $35 \mathrm{~cm}$. DM 125.50 .

This atlas of more than 250 maps and di- agrams, many in color, should be a valuable auxiliary to the study of church history. Plates depicting the growth of Christianity throughout the world range in coverage from Palestine in the time of Christ to contemporary ecumenical developments. There are maps of locations of institutions and of church membership; plans of cities, famous churches, and monasteries; and charts of overall organizational structure of many Christian churches. Signed commentaries of some length, written by specialists, provide historical background, identify authorship or source of the map, and offer bibliographic references. The commentaries, serially numbered to correspond to the places, precede illustrative matter so that reference from one section of the book to the other is necessary. The index of place names on the maps (but not the charts or commentaries) should prove useful.- R.K.

National Union Catalog. A Bibliography of the Catholic Church, Representing Holdings of American Libraries Reported to the National Union Catalog in the Library of Congress. [London], Mansell, 1970. 572p. \$35.

A kind of "spin-off" from the NUC publication project, this volume brings together all the main and added entries for the Catholic Church with all organizational and form headings (about 16,000 entries) from volumes $99-100$ of the National Union Catalog, Pre-1956 Imprints (Suppl. 2AA12). Providing as it does full bibliographic information, cross-references, and library locations this should prove a useful bibliography for the smaller, specialized library or the department library which does not subscribe to the complete pre-1956 catalog. (Such purchasers may experience occasional frustration, however, since cross-references to other volumes of the full catalog are included.) A table of contents, similar to the guides at the beginning of extensive categories in the British Museum Catalogue, would have facilitated use.-E.S.

\section{LITERATURE}

Birmingham, England Public Libraries. Shakespeare Memorial Library. A Shakespeare Bibliography: the Catalogue of the 
Birmingham Shakespeare Library. London: Mansell, 1971. 7v. \$235.

As the catalog of a renowned and extensive Shakespeare library, this work will be welcome in academic reference libraries. It contains all the major and numerous minor editions and translations of Shakespeare's works, as well as an immense body of criticism from all dates and countries: "the literature on Shakespeare's life, the places and times in which he lived, his friends and contemporaries, his sources and influences, the theatre and the court have been brought together into an unexcelled archive."-Introd. The number of volumes in the library is about 40,000 , including, interestingly, some 1,200 items representing the various authorship controversies.

The desirability of publishing such a catalog is undisputed, particularly in view of the many analytics. Unfortunately, however, usefulness is marred by the circumstances of the original catalog itself: the division of pre-1932 and post-1931 accessions, the varying format of those two divisions, the lack of standardization of entries, and the limited bibliographic information for the earlier accessions. All these factors make for an idiosyncratic catalog, but the alternative-recataloging, reformatting, and unifying - would have delayed publication indefinitely and made it prohibitively expensive. Librarians will have to study the introduction to familiarize themselves with variations and peculiarities, but having done so they will find this an especially comprehensive tool.-G.L.

Chicorel Theater Index to Plays in Anthologies, Periodicals, Discs and Tapes. New York: Chicorel Library Publishing Company, [1970- ].v.1- .71-106198.

Marietta Chicorel, ed.

Contents: v.1, Plays in print available in the English language. $\$ 20.75$.

Despite lamentable editing this new play index can be useful to the general reader and the librarian. Covering some 2,000 plays, it lists each by author, title, editor, and anthology or periodical title, all in one alphabetical sequence. The inclusion of collections by a single author is of real value. Complete imprint, as well as price of hardbound and paperbound editions, appears in each entry. Subject approach is provided by an index of subject indicators for national literatures, historical periods, and genres. Unnecessary lists of authors, editors, and play titles are appended, as is a useful list of publishers with addresses.

The introductory matter states that approximately 500 anthologies are covered by 8,500 entries, but whether this refers to the present volume or to the completed set is not clear. Future volumes will list plays in European languages, plays on discs and tapes, and a "guide to the most comprehensive retrospective working collection" (p.xiv). The last description is not explained, and no schedule of publication is mentioned.-R.K.

Foster, David William, and Foster, Virginia Ramos. Manual of Hispanic Bibliography. Seattle: University of Washington Press, [1970]. 206p. \$11. 70-103296.

That the need existed for a good Englishlanguage guide to Hispanic literary studies is without question; that this manual answers the need is very much open to question. Much good and useful information has been brought together here, particularly in the sections on the national bibliography and literature of individual Spanish-American countries, but confidence in the work is undermined by erratic listings in the earlier, general sections. One scarcely expects, for instance, to find the Index Generalis or the World of Learning in a section of general bibliographic guides, but more disturbing is the misinformation found in annotations of numerous standard works. (Constance Winchell probably would be as much surprised to find her Locating Books for Interlibrary Loan listed here as to learn that the 8th edition of her Guide follows a Dewey arrangement.) New editions and supplements are missed with such regularity as to suggest compilation of early sections five or more years ago, without proper updating; frequency and cumulative aspects of continuing series are often ignored or misleadingly noted. A carefully revised and corrected edition of this manual is greatly to be desired.-E.S.

Foster, Ludmila A. Bibliography of Russian Emigré Literature, 1918-1968. Boston: 
G. K. Hall, 1970. 2v. $\$ 60$.

Originally submitted as a doctoral dissertation at Harvard, this bibliography lists creative literature, memoirs, criticism, and diaries written by Russian émigrés and published outside the Soviet Union. Both books and periodical articles are included; omitted are published correspondence, translations into foreign languages, and newspaper material. Arrangement is alphabetical by author, then by form. Citations to bibliographies and biographical material are given when possible. Indexing is by name and genre. One must be grateful to the compiler for having produced the only comprehensive bibliography of Russian émigré literature, an elusive body of writings fraught with such problems as the wide use of pseudonyms, mimeographed publication, serial publication of novels, and so on. Since the bibliography will be indispensable to specialists, then, it is unfortunate that its highly idiosyncratic bibliographic citations and its undifferentiated typography (a reproduction from typescript) make it so difficult to use. A supplement is planned for 1974.-N.S.

Leary, Lewis Gaston. Articles on American Literature, 1950-1967. Comp. with the assistance of Carolyn Bartholet and Catharine Roth. Durham, N.C.: Duke University Press, 1970. 751p. \$20. 70-132027.

To his invaluable list of articles from the first half of this century (Guide BD205) Professor Leary has now added this supplementary volume covering the $1950-67$ period. The quarterly checklists of articles appearing in the periodical American Literature form the basis of the work, but there are numerous additional listings, including a few corrected citations from the earlier volume and an occasional pre-1950 item which was omitted from that publication. The editor notes that, in comparison with the $1900-50$ compilation, this work is both "more inclusive (principally of articles appearing in foreign periodicals) and more selective (in assumptions by the compiler of the value or usefulness of some articles). -Introd. There are again two main sections: listings of articles on individual authors followed by a section arranged under topical subject headings. This is a long- awaited and very welcome bibliography.E.S.

Nilon, Charles H. Bibliography of Bibliographies in American Literature. New York: Bowker, 1970. 483p. \$14.95. 73103542.

This "ordered list of bibliographies and bibliographical tools that provide information on particular authors, works, and topics" (Pref.) is the product of an informal attempt on the part of the compiler to determine the quantity and the variety of forms of American literary bibliography. The work is divided into four basic parts-bibliography, authors, genre, and ancillary-and includes books, essays, and periodical articles. The "ancillary" section includes tools for biography, foreign criticism, music, printing and publishing, and other related topics, thus broadening the scope of the work to the extent that is is of interest to students of American civilization. An index of authors, titles, and authors as subjects is provided. Rather than being cross-referenced, the complete citation is repeated in each appropriate category, making this an especially convenient tool for the student who wants to find material on an individual author or a specific topic.-J.S.

Patterson, Charlotte A., comp. Plays in Periodicals: an Index to English Language Scripts in Twentieth Century Journals. Boston: G. K. Hall, 1970. 240p. \$17. 76-21033.

Originally compiled at the University of Hawaii as part of the library's service to theater communities in the state, this is a useful list of some 4,000 plays in ninetyseven English-language journals published from 1900 through 1968. Main entry is by play title, arranged alphabetically, with author, length of play, cast requirement, and full bibliographical information given. Author and cast analysis indexes add usefulness.-R.K.

Tezla, Albert. Hungarian Authors; a Bibliographical Handbook. Cambridge, Mass.: Belknap Press of Harvard University Press, 1970. 792p. \$25. 74-88813.

Meant to be used with Dr. Tezla's 1964 publication, An Introductory Bibliography 
to the Study of Hungarian Literature (Guide BD872b), this is an expansion of the "major authors" section of that work. It provides as complete a listing as possible of first editions of each of the 162 authors included, as well as many later editions and important bibliographical, biographical, and critical materials relating to them.

A list of abbreviations, symbols, and Hungarian terms used precedes the main body of the work, which is in two parts: the first covering 1450 to 1945 ; the second, 1945 to the present. There are five detailed appendices: (1) a bibliography of studies on Hungarian literature published from 1960 to 1965 , supplementing the citations in the Introductory Bibliography; (2) an annotated list of literary awards, societies, newspapers, and periodicals mentioned in the text; (3) an annotated list of scholarly periodicals with location symbols; (4) a list of all the authors treated, arranged by literary period; and (5) a list of location symbols and libraries. There is an index of authors, translators, compilers, and editors. As in his earlier bibliography, Dr. Tezla has incorporated the highest standards of accuracy and detail, creating a unique reference tool for the study of Hungarian literature. $-E . L$.

\section{Fine Arts}

Khudozhniki narodov SSSR; biobiliograficheskii slovar'. Moskva, Izd. "Iskusstvo," 1970- . v.1- . (In progress)

Contents: v.1, Aavik-Boiko. 4r.

When completed, this work will consist of six volumes containing 20,000 entries on the painters, sculptors, graphic and decorative artists, theater and movie designers, and architects, both native and foreign, who worked in the Soviet Union's republics from ancient times until the present day. Arranged alphabetically, it is compiled by a team of scholars, and draws on information from earlier, less comprehensive compilations. Each article contains a short account of the artist's creative life and a comprehensive bibliography. In v.1 the cut-off date for bibliographical citations is 1964, but this will be more recent for later volumes. Artists known only by initials or nicknames will be treated in the last volume.
An abbreviations list and a bibliography of works frequently referred to in the individual bibliographies complete the first volume of an attractive reference tool which, in its entirety, will be the first fully realized compilation of its kind for Russian art.E.L.

Osborne, Harold, ed. The Oxford Companion to Art. Oxford: Clarendon Press, 1970. 1277p. il. \&6. 71-526168.

Designed both as an introductory handbook to the visual arts and as a guide to further study for the general reader, this is a welcome addition to the Oxford Companion series. Articles, factual in content and written by experts for the nonspecialist, cover the fine arts of all parts of the world from earliest times to the present. Entries for artists, schools, periods, styles, themes, techniques, graphic processes, and surveys of national or regional art appear in one alphabetic sequence. Excluded are theater, cinema, dance, and practical arts and handicrafts, except insofar as these latter are important for understanding artistic development. Illustrations, characterized by the editor as "sparse" although they number in the hundreds, were chosen "to give visual clarification of some technical point ... in the text" (Pref.) without any attempt to make a picture book of the work. Articles do not themselves carry bibliographies, but reference is given to pertinent works in the extensive list of books that concludes the volume and which is intended as a guide for further study. Entries are unsigned; a list of contributors is given. Cross-references add to ease of use. Typeface is small, the double-column page well designed and easily read. Recommended for reference collections large and small.-R.K.

\section{Education}

Grandpré, Marcel de. Glossaire international; termes d'usage courant en matière de certificats d'études secondaires et de diplômes et grades de lenseignement supérieur dans quarante-cinq pays. [Paris], UNESCO, [1969]. 207p. F. 17.50 pa. (Etudes sur les équivalences internationales de diplômes) 77-529052.

This glossary represents the first step in 
a project underway at UNESCO to investigate and compare the various degrees and courses of study offered on the secondary and university levels in all countries possessing systems of higher education. The ultimate goal of the project is to encourage international cooperation in the development of higher education, but any student contemplating study in one of the forty-five countries covered should find this volume useful for determining foreign degree equivalencies. University admissions officers will find it similarly useful. The work is arranged alphabetically by country, and indicates for each academic degree the necessary period of study, prerequisites, required entrance or final examinations, and so on. Definitions are in French, but an English translation is planned. There is a brief bibliography of works on higher education and an index.-N.S.

\section{Sociology}

Adams, John A., and Burke, Joan Martin. Civil Rights; a Current Guide to the People, Organizations, and Events. New York: Bowker, 1970. 194p. \$9.95. 70126010.

"Current guide" aptly describes this handbook which was originally compiled for quick reference use by newsmen, and which "is intended to be a useful book, not a definitive one" (Foreword). An alphabetical directory of individuals and organizations fills the first half of the book, most of the persons included being black. Four appendices follow: (1) Congressional voting records on civil rights bills from 19601968; (2) List of states with civil rights laws and state agencies with civil rights responsibilities; (3) Civil rights chronology, 1954-September 1970; (4) Leading black elected officials in the U.S. Finally, there is a select bibliography of books relevant to the civil rights struggle of the last fifteen years. One hopes that this guide will appear in frequent new editions.-M.M.

Tompkins, Dorothy Louise Campbell Culver, comp. Poverty in the United States During the Sixties; a Bibliography. Berkeley: Institute of Governmental
Studies, University of California, 1970. 542p. $\$ 10$.

The concept of poverty has come to mean more than just inadequacy of food, housing, clothing, and jobs: "Within the past ten years, we have come to recognize that poverty also comprises the gap between a man's dream and his daily life."Foreword. Mrs. Tompkins' exhaustive, annotated bibliography of poverty in the sixties reflects this contemporary view. Various types of materials-books, periodical articles, government publications, dissertations, conference proceedings-from the fields of social welfare, education, health, public administration, sociology, law, agriculture, and economics have been included.

Entries are arranged by broad topics such as "What is poverty?" and "Aspects of life of the poor." Although each item is listed only once according to its major emphasis, the detailed author and subject index provides easy access from related headings as well as to the many analyzed readings. Congresses and symposia are indexed under the heading "conferences"; place names and topical headings such as acculturation, education, employment, and migrant workers are also found in the index. Researchers and librarians will be grateful for the several approaches. The thoroughness and usability of this bibliography will make it a "must" for both social work and general reference libraries.-J.S.

\section{MYTHOLOGY}

Tripp, Edward. Crowell's Handbook of Classical Mythology. [New York], Crowell, [1970]. 631p. \$10. 74-127614.

A concise retelling of the stories surrounding the characters of Greek and Roman mythology, this handbook is intended as a companion for the layman's reading of the classics. Personal and place names, alphabetically arranged, constitute the majority of entries. Each major myth is told once in full under the name of one of its principal characters, and cross-references are made from other characters in the story. The author has attempted to combine varying versions of a myth into a single account, indicating breaks in the tradition. $\mathrm{He}$ has used as sources the best-known versions of 
the myths, all of his citations referring to editions in the Loeb Classical Library except for the works of Hyginus. Because the traditional latinized forms of names are used in the text a pronouncing index of both the Greek and Latin spellings is appended.-M.M.

\section{Political Science}

Röhring, Hans-Helmut, and Sontheimer, Kurt. Handbuch des deutschen Parlamentarismus; das Regierungssystem der Bundesrepublik in 270 Stichworten. München: R. Piper \& Co. Verlag, [1970]. 598p. DM 36.

The student of modern western government with a knowledge of German should be delighted with this compact guide to the government of West Germany. Arranged in alphabetical order with many cross-references, the signed articles were written by scholars of political science who have not only described the institutions and workings of the German political structure, but have tried to be critical and evaluative as well. Any resulting loss of objectivity is at least partially restored by adding bibliographic references at the end of the articles so that the reader may pursue his subject further. The compilers emphasize that they take responsibility only for the comprehensiveness of the work, not for any bias in the individual articles. January 31, 1970, was chosen as the cut-off date for the work. To complete its qualification as a true handbook the volume contains statistical tables, an organization chart of the Bundestag, and lists of government officials from 1949 to 1969 , and makes easily accessible such matters as the order of business of the Bundestag and the duties and privileges of its members.-E.L.

\section{Atlases}

Moore, Patrick. The Atlas of the Universe. New York: Rand McNally, [1970]. 272p. il. \$35. 77-653619.

More than an atlas, this book is almost a layman's encyclopedia in the fields of space exploration and astronomy. It contains basic information on the origin of the earth, moon, and stars, presented in short, well-written essays, and is illustrated with great profusion and beauty. In his foreword Sir Bernard Lovell compares this work to Mercator's atlas of the sixteenth century, in that it attempts to chart a new world that we are about to explore in depth; thus it represents a field of great contemporary interest, and the atlas can be read coverto-cover or referred to as needed. There are tables of stellar objects and their physical attributes, a glossary of astronomical terms, and an index. An "Introduction to the Heavens" provides a useful essay for the amateur astronomer, but in fact the entire book is a useful essay for interested amateurs everywhere, on all aspects of the universe.-G.L.

\section{U.S. Geological Survey. The National Atlas of the United States of America. Wash- ington, $1970.417 \mathrm{p} .49 \mathrm{~cm} . \$ 100.79-$ 654043.}

One of the most exciting and pleasurable publications of recent date is this National Atlas which appears after some eighteen years of planning. No matter what the interest-historical, agricultural, political, economic, climatological-there is a wealth of pertinent information in the 765 maps represented. Data and advice for the maps came from eighty federal agencies and some primary sources, with the source documents indicated to lead to even more information. The atlas is divided between "General Reference Maps" and "Special Subject Maps," and there is an extensive index. The general section consists primarily of locational maps. Thematic or special subject maps, smaller in scale, picture all the various administrative units of the country (counties, judicial districts, civil defense areas, soil conservation districts, etc.), and indicate the "physical, historical, economic, socio-cultural characteristics of the country."-Introd.

A great deal of planning and testing went into the physical composition of the atlas - the paper, coloring, binding, format -in order to provide for clarity, attractiveness, and durability. The editors have succeeded admirably except in one area: the maps which spread over two pages lose their clarity of detail at the binding. The Geological Survey plans completely revised 
editions to be issued periodically rather than loose-leaf replacement sheets to keep the atlas up-to-date.-E.M.

\section{History and Area Studies}

Allworth, Edward. Nationalities of the Soviet East, Publications and Writing Systems; a Bibliographical Directory and Transliteration Tables for Iranian- and Turkic-language Publications, 1818-1945, Located in U.S. Libraries. New York: Columbia University Press, 1971. 440p. \$17.50. 73-110143.

As its subtitle indicates, this is a union list of items in Iranian and Turkic languages located in nine United States research libraries. It includes 3,350 entries for original and translated journals, newspapers, books, and pamphlets in all subject fields except science and technology. The bibliography's particular strengths are in the areas of government and literature, with works from the 1920s and earlier periods predominating; in later years, Russian Communist dominance suppressed the voice of the Soviet Eastern nationalities.

Arrangement is alphabetical by language, subdivided by subject fields. Standard bibliographical information is given, plus library locations, specific issues of periodicals held by a given library, and indication of the alphabet from which the entry was transliterated. The preliminary and final sections indicate the breadth of scholarship involved in compilation of this work. The introductory essay, "Research on Nationalities of the Soviet East," is an informative survey of the new trends of American scholarship in this area, including discussion of American library resources for such research and the problems in the acquisition of research materials. The concluding section is a set of transliteration tables for the twenty-six Iranian and Turkic languages, with their eighty-six alphabets and six writing systems.-D.G.

Davies, Godfrey. Bibliography of British History: Stuart Period, 1603-1714. 2d ed.; ed. by Mary Frear Keeler. Oxford: Clarendon Press, 1970. 734p. \&5.

So long a time has passed since the initial appearance of this bibliography (Guide
DC110) it seems unfortunate that the new edition should be almost ten years out of date on publication. The cut-off date is mainly 1962 for books and 1958 for periodical articles, although selected items of later date are listed in both categories. Professor Keeler's edition represents a complete revision, expansion, and updating of the Davies volume; there are 4,350 numbered items, plus many additional references in the notes and annotations. The work was issued under the direction of the American Historical Association and the Royal Historical Society of Great Britain and will, of course, be the standard bibliography for this period of British history for years to come.-E.S.

\section{Directory of Afro-American Resources.}

Walter Schatz, comp. New York: Bowker, 1970. 485p. \$19.95. 71-126008.

By means of questionnaires, telephone calls, and personal interviews, workers at the Race Relations Information Center of Nashville have assembled a directory of "organizations and institutions in the United States holding materials which document the history and experience of black Americans."-Pref. Institutions and organizations range from colleges and universities to government agencies, from civil rights programs to radical and extremist groups. More than just a listing, this book describes the collections and points out special source materials-manuscripts and documents-in each repository. Entries are arranged by state and by city, then alphabetically by name of institution or organization. Each entry gives the fullest possible information: address, person to whom enquiries should be addressed, statement of purpose of the organization, and important publications. An index provides reference by subject, person, place, or institution.

American historians will find the compilation extremely helpful. The addresses, descriptions of contents and guides to collections, and the location of specific papers open many resources virtually unknown or previously discovered only by great investment of time and energy, or by sheer luck. The compiler and the publisher are to be complimented for having produced a very usable and needed reference work.-E.M. 
Harper Encyclopedia of the Modern World; a Concise Reference History from 1760 to the Present. Ed. by Richard B. Morris and Graham W. Irwin. New York: Harper \& Row, [1970]. 1271p. \$17.50. 73-81879.

The editors have here attempted to summarize the essential facts of world history since 1760. The work is composed of two major parts: a basic chronology and a topical chronology. The former relates political, military, and diplomatic history within the following categories: The Democratic Revolution in the Western World, 17601825; The Asian and African Worlds, 1760 1870; The Age of Western Nationalism, 1789-1914; The Age of Imperial Rivalry, 1870-1914; The Era of World War, 19141945; The Postwar World, 1945-1968. Economic, social, and constitutional history are treated in the topical chronology under the sections entitled "Economic Development and Technology in an Age of Revolution" and "Government and Society in an Age of Revolution." In addition, the history of science and of thought and culture are capsulated in the sections on "The Revolution in Science" and "Thought and Culture in an Age of Revolution." The more limited period of coverage aside, it is these latter sections which probably most distinguish this volume from Langer's Encyclopedia of World History (Suppl. 2DA5).-J.S.

Webster's Guide to American History; a
Chronological, Geographical, and Biographical Survey and Compendium. Springfield, Mass.: G. \& C. Merriam, [1971]. 1428p. il. \$14.95.

In view of frequent revisions and updatings of Carruth's Encyclopedia of American Facts and Dates (Suppl. 1DB4) and Morris's Encyclopedia of American History (Suppl. 1DB6), plus the recent appearance of the Oxford Companion to American History (Suppl. 1DB5), one cannot but question the need for this work. Grant, however, that the editors have combined characteristics of earlier works with some new features and have come up with a fairly attractive package.

The work is in three parts plus an index. Part I comprises a chronology of events (1492-1969), with excerpts from contemporary documents, speeches, letters, etc., appearing in parallel columns. These excerpts, unfortunately, are not always precisely identified. Part II offers a section of tables and maps (many in color); and Part III contains biographies of more than a thousand notable Americans, including some living persons. Most sketches run about a column or more in length and they constitute one of the outstanding features of the work. While not an essential purchase for libraries holding similar handbooks, the volume recommends itself for the home library or the student's personal reference shelf.-E.S. 